\title{
When it comes to the crunch: \\ What are the drivers of the US banking crisis?
}

\author{
Eliot Heilpern \\ Colin Haslam* \\ Director Centre for Research in Finance and Accounting \\ University of Hertfordshire \\ Tord Andersson \\ Centre for Research in Finance and Accounting \\ University of Hertfordshire
}

\begin{abstract}
About the authors
Eliot Heilpern

Holds the post of Vice President for International Payment and Trade Services at a major global financial institution in the City of London. Previous roles were with the IBOS Banking Cash Management Group, 11years with a UK Clearing Bank, and four years with a private investment bank.

Colin Haslam

Is Director of the Centre for Research in Finance and Accounting (CRiFA) at the University of Hertfordshire

Tord Andersson

Is a visiting lecturer in finance at the University of Hertfordshire and Business Adviser in Sweden. Having previously worked as financial analyst for 14 years, at Skandia/DnB Asset Management, UBS Warburg and Handelsbanken, and 8 years as product manager at Ericsson

* Contact

c.j.haslam@herts.ac.uk

$\underline{\text { Acknowledgements }}$
\end{abstract}

We would like to thanks Dr Nick Tsitsianis and Dr Edward Lee of CRiFA for their contributions to this article and observations from Professor Geoff Hodgeson. 


\begin{abstract}
This article considers how permissive regulatory conditions helped change the size and scope of the US mortgage market. Asset backed securitization facilitated an expansion of the US mortgage market and modified the structure of the value chain within which financial assets, risk and liquidity were managed. New sophisticated mortgage products, indulgent lending practices, loose credit assessment and flimsy documentation increased the probability of mortgage default in an economic downturn. US banks were not in a position to absorb mark to market losses on mortgage assets and goodwill impairment resulting from a credit crunch because they operate with narrow profit margins and a limited equity cushion in the balance sheet. This article questions the viability and sustainability of this banking business model.
\end{abstract}

Keywords: US credit crisis, mortgage securitization, financial value chain, risk and liquidity. 
When it comes to the crunch: what are the drivers of the US banking crisis?

"We remain conscious that since substantial risk still remains on our balance sheet, these factors will likely affect our business for the remainder of the year or longer.”

J.P. Morgan Chase CEO Jamie Dimon July $17^{\text {th }} 2008$

\section{$\underline{1 . \text { Introduction }}$}

The current "credit crunch" emerged as a serious problem for the US economy towards the end of 2006 when charge off's and default rates on sub-prime higher risk loans increased. A growing number of US households either could not repay existing mortgage debt (charged off) or defaulted (repayment schedules not met). The financial risk attached to sub-prime mortgages was less of a problem when US home prices inflated and household's could not only trade up but also extract additional cash resources from equity release schemes. Charge offs and the rate of mortgage loan delinquency increased towards the end of year 2006 and this upward trend continued into 2008. Charge offs are written off at fair value against bank balance sheet assets seriously undermining banking sector net income, market valuation, shareholder equity, and capital market liquidity.

Asset backed securitization permitted the banking sector to issue mortgages ahead of deposits, such that the value of outstanding mortgages in the US at the end of 2007 exceeded annual national income. As US house prices fall mortgage charge off and default rates increased forcing mark to market write offs of irrecoverable mortgages and the fire sale of collateral through 2007 and into 2008. The initial increase in mortgage charges offs threatened the financial stability of the banking sector in the US with follow on consequences for capital market liquidity. US banks became reluctant to lend to each other as they defensively restructured balance sheets holding on to cash as a liquidity hedge.

Mortgage backed securitization provided US banks with a way to extend their lending capacity whilst also containing balance sheet risk associated with this process. Banking executives paid substantial financial incentives to grow the product market with new product 
such as variable rate "pick and pay" mortgages all of which served to extend the value of balance sheet securitized mortgages. US households were actively encouraged to finance current expenditure from mortgage equity withdrawal (MEW). Economists differentiate between wealth and income whereby house price inflation is simply accumulated wealth on paper. Yet mortgage equity withdrawal is about leveraging additional cash from the difference between the current market value of real estate and current mortgage debt outstanding. In turn, this additional source of household income finds its way into current income and expenditure circuits that make up annual Gross Domestic Product (GDP).

The value of US household mortgages outstanding at the end of 2007 was roughly \$11 trillion and it only needed a relatively small increase in the default rate for this to have a significant negative impact on the banking sector net income and condition of balance sheets. Mortgage charge off's are no longer restricted to sub-prime mortgages and Jamie Dimon's quote is significant because the problem of mortgage charge off and delinquency has spread beyond sub-prime and into so-called Alt A rated loans.

In 2007, estimates suggested that $\$ 2$ trillion out of the $\$ 11$ trillion of outstanding mortgages were sub-prime in 2007. The exact definition of "subprime" itself is not clear, with various sources estimating that the total subprime portfolio of the US is between $\$ 1.5$ trillion to \$3 trillion.

http://goldnews.bullionvault.com/subprime_sub_prime_gold_dollar_bernanke_111420073

For the year end 2008 loan charge offs and delinquency rates on loans secured by real estate stood at roughly 10 per cent of all real estate mortgages outstanding compared to $1.5 \%$ in mid-2006. If we assume that mortgages currently delinquent were also to be subsequently charged off this would result in a cumulative write down approaching \$1 trillion and equivalent to writing off all shareholder equity in main US banks at December 2008.

In the US financialized economy a combination of regulatory permissiveness driven on by managerial incentives and household demand for credit forced outstanding mortgages ahead of GDP. Domestic real estate prices are down 27\% December 2008 compared to June 2006 (S\&P-Case Shiller Index) in the US. The ABX index that tracks the value of sub-prime credit swaps reinforcing evidence of substantial negative mark to market adjustments both in the 
sub-prime market and to a lesser extent in AAA rated mortgage portfolios as US house prices, for high and low income households, are marked down.

This article has three sections. The first section of this article we review the literature on financialization as it applies to the development of the US economy. The literature on financialization explores the tension between financial and productive logic(s) governing the management of the economy, social settlements and governance. Our second section reviews how modifications to the legal and accounting regulations governing the banking value chain encouraged fragmentation and out-sourcing connected with the process of mortgage securitization. Our final section considers the implications of managing a financialized banking sector. Where, the scale of financial assets under management combines with mark to market accounting to amplify instability especially when US banks operate with a fragile financial operating architecture. Net income and shareholder equity offer a limited cushion against mark to market write down(s) and this fragility calls into question the viability and sustainability of the US banking business model.

\section{Mortgaging US households}

We employ the descriptor 'financialization' as a way of 'making sense out of what is going on around us' (Martin, 2002). The term 'financialization' has been employed to reveal, how: managerial behaviour and culture, corporate governance, stakeholder interests, firm performance, structural economic adjustment, national economic competitiveness and the distribution of income and wealth that are modified by the demands of finance capital (Deeg et al 2006; Fligstein 2004; Froud et al, 2006; Kripner, 2005, Rossman et al, 2006; Stockhammer, 2004). Financialization describes a process of economic change in which the structure of advanced economies has shifted increasingly towards the provision of financial services and where the value of financial assets exceeds that of tangible assets. Foster (2007) notes that:

\footnotetext{
"Although orthodox economists have long assumed that productive investment and financial investment are tied together-working on the simplistic assumption that the saver purchases a financial claim to real assets from the entrepreneur who then uses the money thus acquired to expand production — this has long been known to be false. There is no necessary direct connection between productive investment and the
} 
amassing of financial assets. It is thus possible for the two to be "decoupled" to a considerable degree”

(Foster 2007 http://marxsite.com/Finance_Capital.html)

Foster provides a way of thinking about the process of financialization as one in which there is a decoupling of financial from productive tangible asset investment. Our supplementary argument is that financialization is not simply a process of decoupling wealth accumulation from current income circuits as described by Foster. It is also concerned with how the gains (and losses) from wealth accumulation (capital stock) interfere with current income circuits (flows) within national economies and the consequences of this for economic development and financial stability of firms.

Gross fixed capital formation (GFCF) generally follows the trend of GDP in the US and specifically the stock of residential domestic real estate formation followed the general trend of GDP growth 1963 to 2007. For the period 1963 - 2005, the value of new residential housing GFCF tracked GDP apart from a step reduction in the early 1990s. The index of real estate GFCF reveals how fixed asset capital formation tracks GDP but this is not the same thing as financing the purchase of real estate and specifically the growth in household mortgages outstanding.

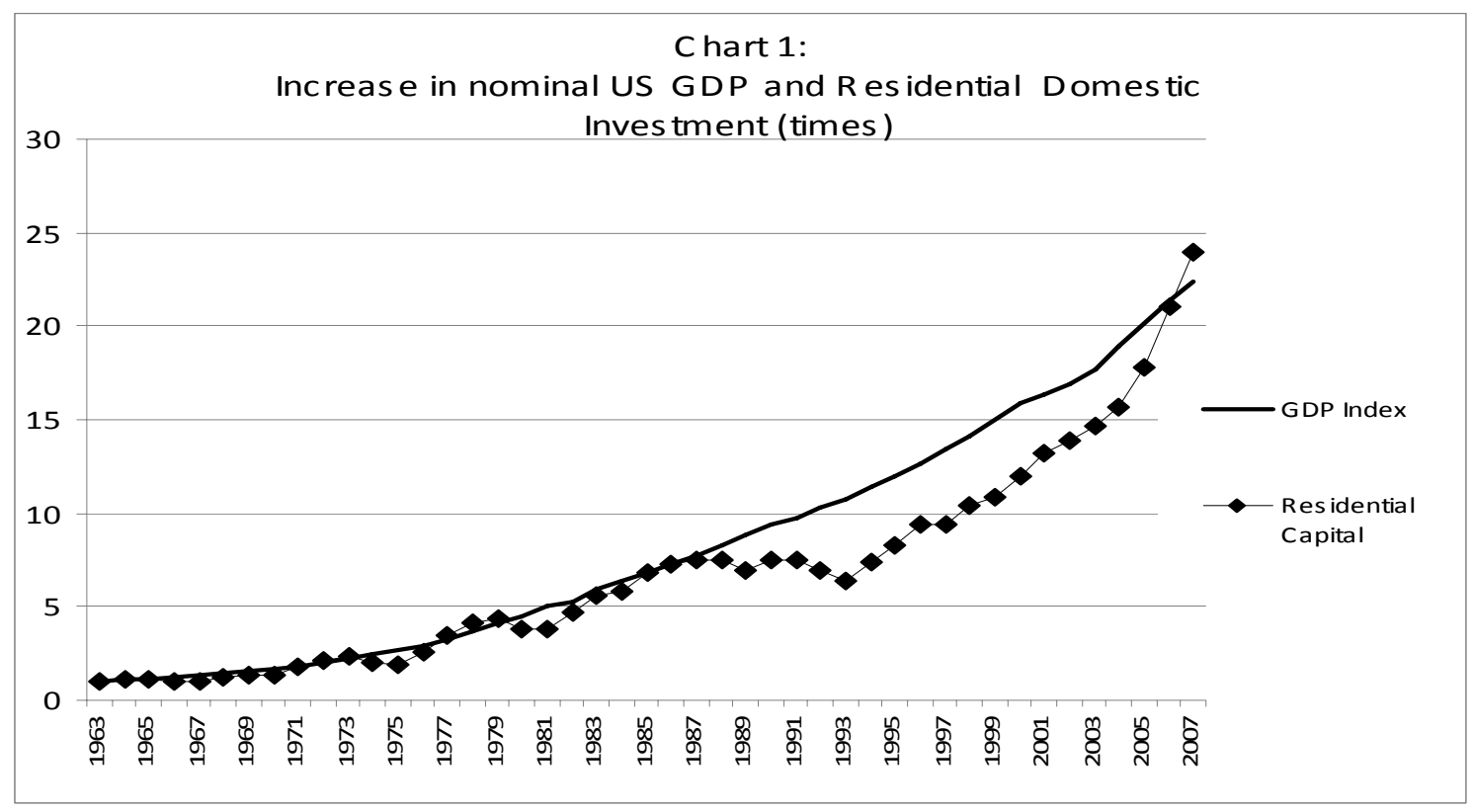

Source: http://www.bea.gov/ 
In contrast, the pattern of outstanding mortgages held by US households follows a different trajectory over the period 1963 to 2007. For the first twenty years (1963-1983) the nominal value of outstanding household mortgages and GDP move in line with each at a compound average growth rate (CAGR) of 9\%. Thereafter the two trajectories diverge. The value of the stock of outstanding real estate mortgages continues at its earlier CAGR of $9 \%$ but nominal GDP growth slows to a CAGR of 5.3\% 1983 to 2007.

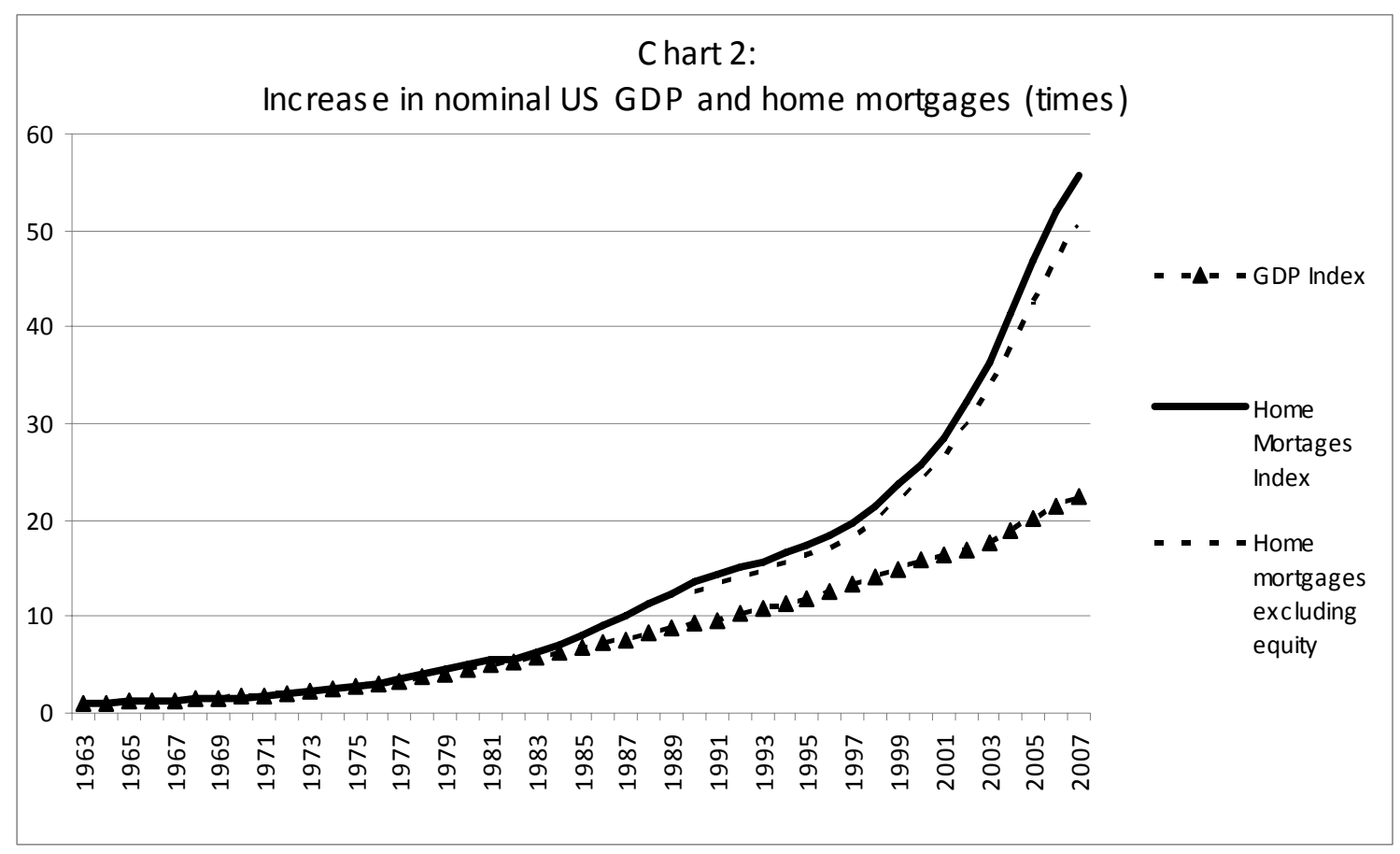

Sources: Mortgage data http://www.federalreserve.gov/releases/z1/

GDP data: http://www.bea.gov/

The decoupling of the value of mortgages outstanding from GDP growth is explained by the compounding effect of house price inflation coupled with the growth in the physical stock of residential houses in the US from 60 million in 1963 to 120 million in 2007. To which it is also necessary to add "home equity release mortgages" which had increased to $\$ 1.1$ trillion as at the end of 2007 or $9 \%$ of the value of outstanding mortgages in 2007. 
Table 1: US GDP and household mortgages outstanding in 2007 (\$trillion)

\begin{tabular}{|l|c|}
\hline & 2007 \$ trillion \\
\hline US GDP & 13.8 \\
\hline Outstanding home mortgages & 12.0 \\
\hline Of which equity mortgages & 1.1 \\
\hline
\end{tabular}

Source: http://www.federalreserve.gov/releases/z1/

Many US households have been actively leveraging their borrowing from what are termed "home equity lines of credit" and this has further increased the value of outstanding mortgage debt.

The Federal Reserve Board provides the following advice.

More and more lenders are offering home equity lines of credit. By using the equity in your home, you may qualify for a sizable amount of credit, available for use when and how you please, at an interest rate that is relatively low. Furthermore, under the tax law--depending on your specific situation--you may be allowed to deduct the interest because the debt is secured by your home”.

A home equity line of credit is a form of revolving credit in which your home serves as collateral. Because the home is likely to be a consumer's largest asset, many homeowners use their credit lines only for major items such as education, home improvements, or medical bills and not for day-to-day expenses.

Once approved for a home equity line of credit, you will most likely be able to borrow up to your credit limit whenever you want. Typically, you will use special checks to draw on your line. Under some plans, borrowers can use a credit card or other means to draw on the line.

http://www.federalreserve.gov/pubs/HomeLine/

The following example demonstrates the financial calculations involved.

\begin{tabular}{|lc|}
\hline Appraised value of home & $\$ 100,000$ \\
Percentage & $\mathrm{x} 75 \%$ \\
Percentage of appraised value & $\$ 75,000$ \\
Less balance owed on mortgage & $\$ 40,000$ \\
Potential line of credit & $\$ 35,000$ \\
\hline
\end{tabular}

http://www.federalreserve.gov/pubs/HomeLine/default.htm\#equity 
The value of potential line of credit is three-quarters of the appraised value of a home minus the value of mortgages owed and US households have been actively leveraging their borrowing exploiting "home equity lines of credit". At the end of 2007, the value of accumulated equity release secured against real estate had increased to 9 per cent of outstanding mortgage debt in 2007 or \$1.1 trillion.

Table 2: US Home and equity release mortgages outstanding 1990 to 2007

\begin{tabular}{|c|c|c|c|}
\hline & $\begin{array}{c}\text { Home mortgages } \\
\$ \text { bill }\end{array}$ & $\begin{array}{c}\text { Equity Mortgages } \\
\$ \text { bill }\end{array}$ & $\begin{array}{c}\text { Equity Share in total } \\
\%\end{array}$ \\
\hline 1990 & 2911.6 & 214.7 & 7.4 \\
\hline 1991 & 3075.1 & 222 & 7.2 \\
\hline 1992 & 3227.7 & 217.1 & 6.7 \\
\hline 1993 & 3384 & 210.4 & 6.2 \\
\hline 1994 & 3562.6 & 221.8 & 6.2 \\
\hline 1995 & 3736.1 & 237.5 & 6.4 \\
\hline 1996 & 3972.3 & 262.6 & 6.6 \\
\hline 1997 & 4218.9 & 297 & 7.0 \\
\hline 1998 & 4609.3 & 309.9 & 6.7 \\
\hline 1999 & 5076.5 & 334.3 & 6.6 \\
\hline 2000 & 5533.7 & 407.9 & 7.4 \\
\hline 2001 & 6127.4 & 438.9 & 7.2 \\
\hline 2002 & 6924.6 & 500.7 & 7.6 \\
\hline 2003 & 7795.4 & 592.8 & 8.7 \\
\hline 2004 & 8891.3 & 773.3 & 9.1 \\
\hline 2005 & 10067.1 & 911.6 & 9.5 \\
\hline 2006 & 11192.9 & 1060.8 & 9.4 \\
\hline 2007 & 11995.5 & 1125 & \\
\hline
\end{tabular}

Source: http://www.federalreserve.gov/releases/z1/Current/annuals/a2005-2007.pdf Note: Data for this table from Table L218 see also memo item in table

The growth in outstanding household mortgages, relative to GDP growth, in the US reflects the combined effects of: increased demand for housing, compound price inflation and equity release mortgages. The value of US household mortgages outstanding has, since the early 1980s, run ahead of GDP growth (see Chart 2). From a position where outstanding home mortgages were equivalent to one-third (in 1963) then one-half (in 1990) of GDP they are now roughly equivalent to US annual GDP. The break between GDP and value of mortgages outstanding coincides with changes in banking regulation and accounting practices in the mid 1980s The composition of the mortgage market changed from a system based on deposits to one of securitized assets. Until the early 1980's the majority of the US mortgage market was 
structured by deposits (70\%) but by 2005 this picture had reversed with securitized assets accounting for $60 \%$ of the market.

Chart 3: Mortgage Market Structure (percent composition in the US)

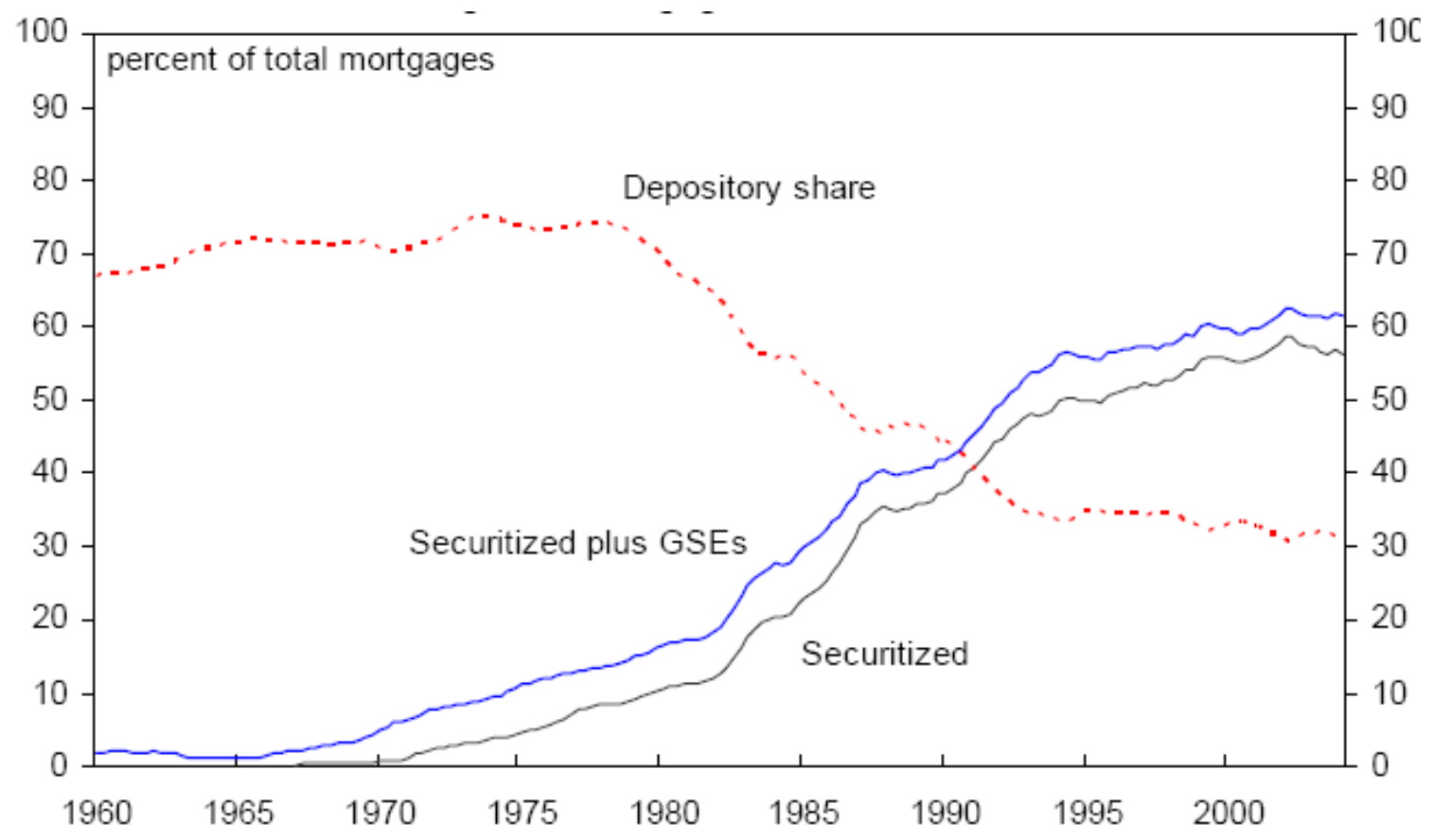

Source: Schnure 2005, figure 2

The Savings and Loan crisis in the 1980's changed the system for US housing finance from local and regional balance sheet lending by depositories to a national market based system of securities mortgage finance (Schnure 2005). Securitization of assets involves repackaging and selling off balance sheet assets such as mortgages into a secondary market. Mortgage backed securitization allowed banks to modify their balance sheet risk exposure (and cost of capital) and significantly raise additional cash resources for lending to households. Securitization provided banks with the financial capability to increase the supply of mortgage funds to an increasing number of home owning households paying more for their properties. Chart 3 reveals the changing financial structure of the mortgage market. Initially bank deposits accounted for approximately 70 per cent of the total mortgage market but by the mid to late 1980s securitized mortgages take an increased share of total mortgage finance reaching $65 \%$ by 2005. 
Recent US house price appreciation also helped to enlarge the size and scope of secondary markets for securities backed by non-prime mortgage loans at a time when the system of US housing finance changed profoundly (Frankel 2006). A point also observed by Greenspan (2005):

“... over the past two decades, major innovations in the United States have improved the availability and lowered costs of home mortgages. These developments likely spurred home owners to increasing home equity to finance consumer expenditure beyond home purchase"

The sharp rise in US home prices also coincides with a competitive pressure on lenders to develop non-traditional loan products, such as Adjustable-Rate Mortgages (ARM), and the Pick a Payment loan(s) where non-agency mortgage underwriters took an increasing share of US housing finance and especially that for sub-prime borrowers. Another development in the mortgage market was the emergence of intermediary brokers and use of technology for rapid decisions, for example, automated underwriting systems with credit history scoring for pricing of mortgages and default risks. The system of US mortgage finance is thus an outcome of regulatory reform and market based responses that fragment the financial value chain into specialist roles, each with its own business interest and objectives, which complicates responsibility and solutions (FRB 2007, Frankel 2006, Krinsman 2007)

Changes in the mortgage product market and investment in non-agency securities now involves banks in exposure to both prepayment and default risk (as a result of credit risk exposure) in addition to the more traditional risk associated with changes in interest rates. These new risks, initially obscured by inflated house prices, have now become increasingly apparent now that prices are falling. The earlier growth and demand for subprime asset backed securities, often repacked into Collateral Debt Obligations (CDO), have faded away as liquidity dried up. (Frankel 2006, Krinsman 2007)

The availability of finance was, in these circumstances, no longer subject to monetary policy restrictions, rather prices and liquidity in national and international bond markets mattered. Mortgage backed securities were sold on to investors that had varying appetites for risk where sub-prime mortgage debt was blended with AAA rated mortgages and "wrapped” up for investors. Bundling and blending products with varying types of credit risk met with 
general "technical" approval because the process of diversification between high and low rates credit risk wrapped up into portfolios would both spread and limit risk.

With sufficient controls and the necessary infrastructure in place, securitization offers several advantages over the traditional bank-lending model. These benefits, which may increase the soundness and efficiency of the credit extension process, can include a more efficient origination process, better risk diversification, and improved liquidity.

\section{http://www.occ.treas.gov/handbook/assetsec.pdf}

Banking executives were encouraged to pass on ever more complex collateralized products to investors to value skim, improve banking returns and their own bonuses. Financial incentives focused attention on the construction of financial products that modified credit rating, risk, and financial return to the banks at the expense of liquidity. Liquidity depends on the continued repayment of interest and principal sums by households on their mortgages. The increase in household mortgage charge offs and loan delinquency rates doubly exposes the financial sector because leveraged funding of mortgages coupled with mark to market accounting amplifies adjustments. Asset write-downs (holding losses) have severely damaged reported net income, market values and shareholder equity and now call into question the viability of the US banking sector business model. The complexity of the web of financial transactions surrounding the process of asset securitization makes it difficult to assess risk exposure from household payment default and counterparty risk with the result that banks are holding on to cash balances to protect liquidity even after Government bailout(s).

\section{Mortgage securitization: disintermediation, outsourcing and institutional risk}

We have noted how GDP growth and the value of mortgages outstanding for US households diverged during the period 1980 to 2007 . This decoupling is on the one hand a reflection of inflated house prices combined with a growth in the outstanding stock of residential housing stock increasing household demand for mortgages. This break also coincided, as we have noted, with a change in US banking regulations and market demand. The US banking sector operated under a "retain and hold” policy up to the 1980s where customer deposits and their matching assets held on balance sheet. Growth in mortgage lending generally tracked the increase in investor deposits and thrift funds. The 1980s marked a break with the past because regulations now permitted banks to "repackage and sell on" assets held on balance sheet into 
a secondary market. This change in regulatory framework promoted substantial growth in mortgage-backed securities, that is, bonds whose cash flows are backed-up by household mortgage repayments.

Altunbas et al (2007) reveal that asset securitization both increased bank liquidity and served to transfer credit risk off balance sheet into the wider financial market.

First, asset securitization increases banks' liquidity while reducing banks' funding needs in the event of monetary tightening. Second, securitization allows banks to swiftly transfer part of their credit risk to the markets (including institutional investors such as hedge funds, insurance companies and pension funds) thereby reducing their regulatory requirements on capital. (Altunbas et al, 2007: 6)

In their paper for the European Central Bank Altunbas explore how securitization modifies the monetary transmission mechanism increasing liquidity (even if there is monetary tightening). In addition, they observe that:

Securitisation activity has also strengthened the capacity of banks to supply new loans to households and firms for a given amount of funding. (Altunbas et al, 2007:10)

Securitization allows banks to remove and repackage assets that have built up on a bank's balance sheet and sell these on in a secondary market. Credit risk is removed from the banks balance sheet and cash reserves increased as loans are sold on. In turn, the reduction in both credit risk and increased cash in hand on balance sheet provides banks with the regulatory ability to raise additional loans for new or existing customers.

In the US from the post-war period up until the late 1970s investor deposits and diverted thrift savings had been the main source of funding for mortgage loans. The funding available for mortgages drifted upwards in line with the growth in national income and savings. However financing mortgages from checkable deposits and thrift savings was problematic because of the short-term volatility connected with this type of funding. Using short-term deposits to finance long-term debt involved not only reconciling timing differences but there was the added uncertainty relating to the inflow of deposits against which new additional mortgages could be raised (see Chart 4). A secondary market would permit banks to sell mortgages they had originated to other investors to raise additional cash funding upon which they could increase the volume of mortgage lending. The advantage of asset securitisation is 
that it shifts the banking system from the principle of "retain and hold" to one of "repackage and sell on” to lever funds for lending. However, the process of securitisation can contribute to the greater retention by banks of "toxic waste", that is "assets that are particularly illiquid and vulnerable to changes in macroeconomic performance” (Duffe 2007).

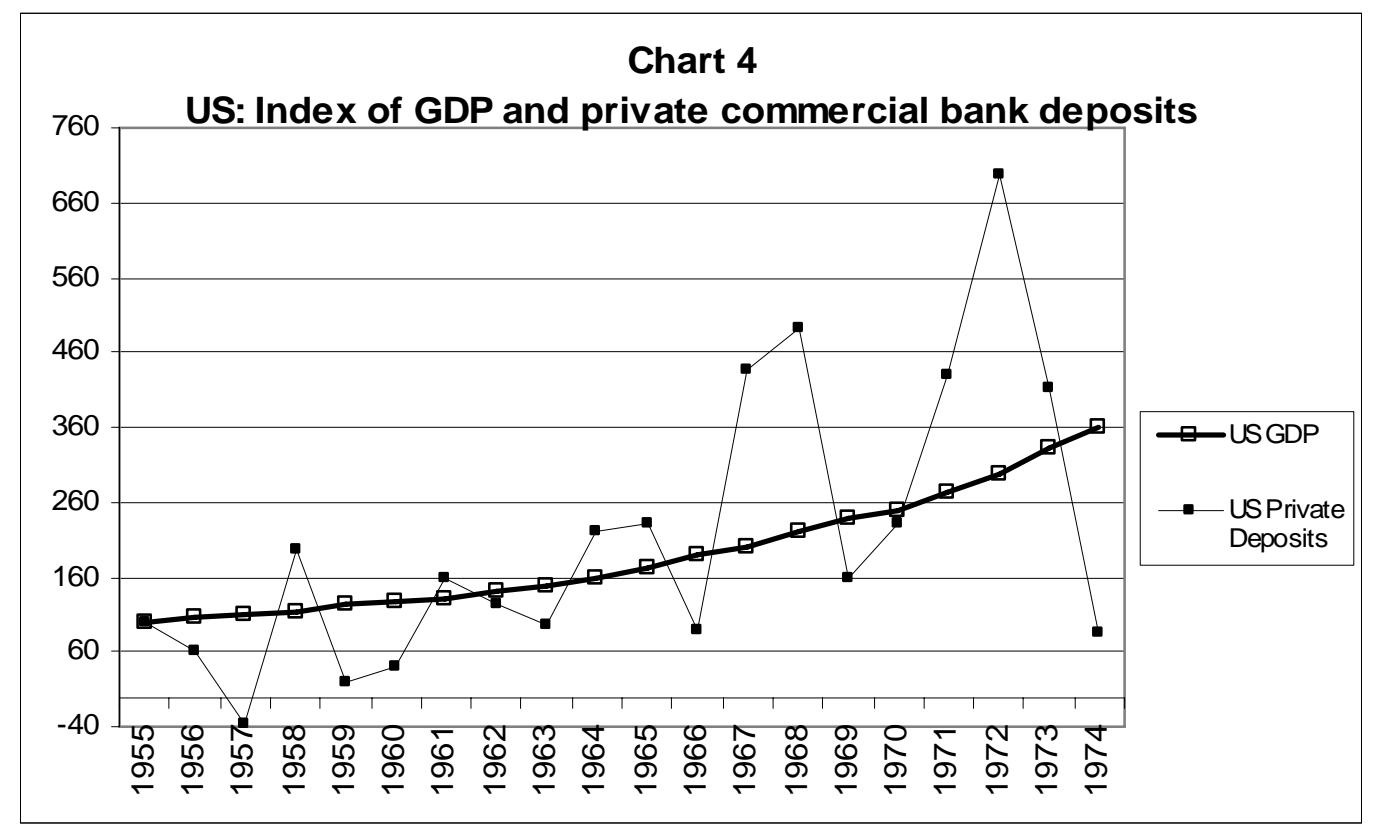

Source: http://www.federalreserve.gov/releases/z1/

Note: Information taken from flow of funds accounts table F110: US chartered commercial banks

Now that US banks could sell on loans to investors this transformed the role of financial intermediaries in the mortgage market from "buying and holding" to "buying and selling" (Keys et al 2008). Although securitization is concerned with transferring financial risk out from the banking system, banks were among the most active buyers of structured products and, as such, credit risk remained in the banking system (Duffe, 2007). The increased distance between loan originators and the ultimate bearers of risk potentially reduced lenders incentives to carefully screen and monitor borrowers (Petersen et al 2002). The increased complexity of financial products and markets also reduces investor's ability to value them correctly. This is especially valid for structured products were the value depends on the correlation structure of default events.

The pooling and securitization of credits is the result of financial innovations and adoption of a new banking business model.

"Credit is now something that is largely bought and sold on the market, rather than held for the long term on the balance sheet of financial intermediaries” (Draghi 2007) 
In the US, the process of mortgage asset backed securitization developed earlier than in Europe. According to Geradi et al (2006), two regulatory adjustments facilitated the growth of securitization in the US. The first of these was a modified accounting regulation introduced by The Federal Home Loan Bank Board (FHLBB) in October 1981. According to Geradi this allowed lenders to sell mortgages on into a secondary market without the need to account for the losses attached to this transaction (citing Mason, 2004). The second related to the fact that Government Sponsored Enterprise's (GSE's) including Fannie Mae (Federal National Mortgage Association) and Freddie Mac (The Federal Home Loan Bank Board) were exempt from state investor protection laws. Jacobides (2003) adds the insightful and additional dimension of “organizational unbundling” a concept employed to explain how latent financial gains from trade are released. For example as between primary and secondary markets or between loan origination and managing capital risk such that "once the securitizers managed to find a way of creating marketable securities, finding willing institutions or investors only too happy to buy the loans without the hassle of producing them was easy” (Follain and Zorn, 1990 cited in Jacobides, 2003: 23)

The whole aspect of asset securitisation and collateralisation was favoured by banks. It first allowed banks to remove from their balance sheets more of the credit they themselves originated thereby earning income without tying up significant amounts of regulatory capital. Secondly, banks could obtain a relatively cheap wholesale funding by packaging up their mortgages and selling these off, while simultaneously raising further funds in the capital markets through issuing asset-backed securities where the assets that are physically backing the securities issued are the "packaged" mortgages themselves. 
Table 3: US securitization trends total and mortgage backed

\begin{tabular}{|c|c|c|c|c|}
\hline & $\begin{array}{c}\text { Trends in } \\
\text { securitisation } \\
\text { issuance }\end{array}$ & $\begin{array}{c}\text { Annual mortgage } \\
\text { backed }\end{array}$ & $\begin{array}{c}\text { Total US } \\
\text { household } \\
\text { mortgages }\end{array}$ & $\begin{array}{c}\text { Securitized } \\
\text { mortgages as a \% } \\
\text { of total household } \\
\text { mortgages }\end{array}$ \\
\hline & \$bn & \$bn & \$bn & 13.0 \\
\hline 1990 & & 377.6 & 2911.6 & 16.6 \\
\hline 1991 & & 510.4 & 3075.1 & 26.4 \\
\hline 1992 & & 850.6 & 3227.7 & 29.4 \\
\hline 1993 & & 994.8 & 3384 & 16.0 \\
\hline 1994 & & 571.5 & 3562.6 & 9.3 \\
\hline 1995 & & 348.2 & 3736.1 & 12.8 \\
\hline 1996 & 661.0 & 507.8 & 3972.3 & 25.2 \\
\hline 1997 & 827.5 & 639.7 & 4218.9 & 20.6 \\
\hline 1998 & 1430.5 & 1166.3 & 4609.3 & 12.8 \\
\hline 1999 & 1312.5 & 1046.2 & 5076.5 & 27.3 \\
\hline 2000 & 1021.4 & 708.5 & 5533.7 & 32.2 \\
\hline 2001 & 2054.6 & 1672.1 & 6127.4 & 39.4 \\
\hline 2002 & 2718.4 & 2228.3 & 6924.6 & 19.8 \\
\hline 2003 & 3671.3 & 3071.0 & 7795.4 & 19.5 \\
\hline 2004 & 2648.8 & 1762.6 & 8891.3 & 17.3 \\
\hline 2005 & 3138.8 & 1966.4 & 10067.1 & 16.9 \\
\hline 2006 & 3240.9 & 1934.0 & 11192.9 & \\
\hline 2007 & 2892.3 & 2027.0 & 11995.5 & \\
\hline
\end{tabular}

Sources; Securitization data

http://www.ifsl.org.uk/output/ReportItem.aspx?NewsID=25

US outstanding household mortgages: Flow of Funds annual data

http://www.federalreserve.gov/releases/z1/Current/data.htm

Throughout the 1990's there was a steady growth in the rate of asset securitization and specifically mortgage backed securitization in the US. For the period 1996 to 2007 mortgage backed securities account for three-quarters of the annual US securitization market. At its peak (2003) the share of US outstanding mortgages being securitized on an annual basis reached roughly 40 per cent before dropping off to levels below 20 per cent.

The development of asset-backed securitization modifies the financial value chain. The value chain for the purposes of this paper is the overall space that encompasses the physical business communications, logistical, financial, and administrative process, which resides between the buyer and seller as part of any commercial legal transaction. Securitization increased the demand for outsourcing especially to specialists who can provide technical and credit risk management (where banks cannot). The aim is to satisfy all parties: the bank, the depositors, the shareholders, and ultimately the regulatory authorities. This "technical 
cushion” providing a seemingly perceived transparent working order to the industry, but results in additional financial intermediation. The securitized product would then need to be re-priced to include for instance outsourcing fees, risk assessment internally, which may have to be further re-assessed and confirmed by external risk specialists.

Fig 1: Banking Value Chain

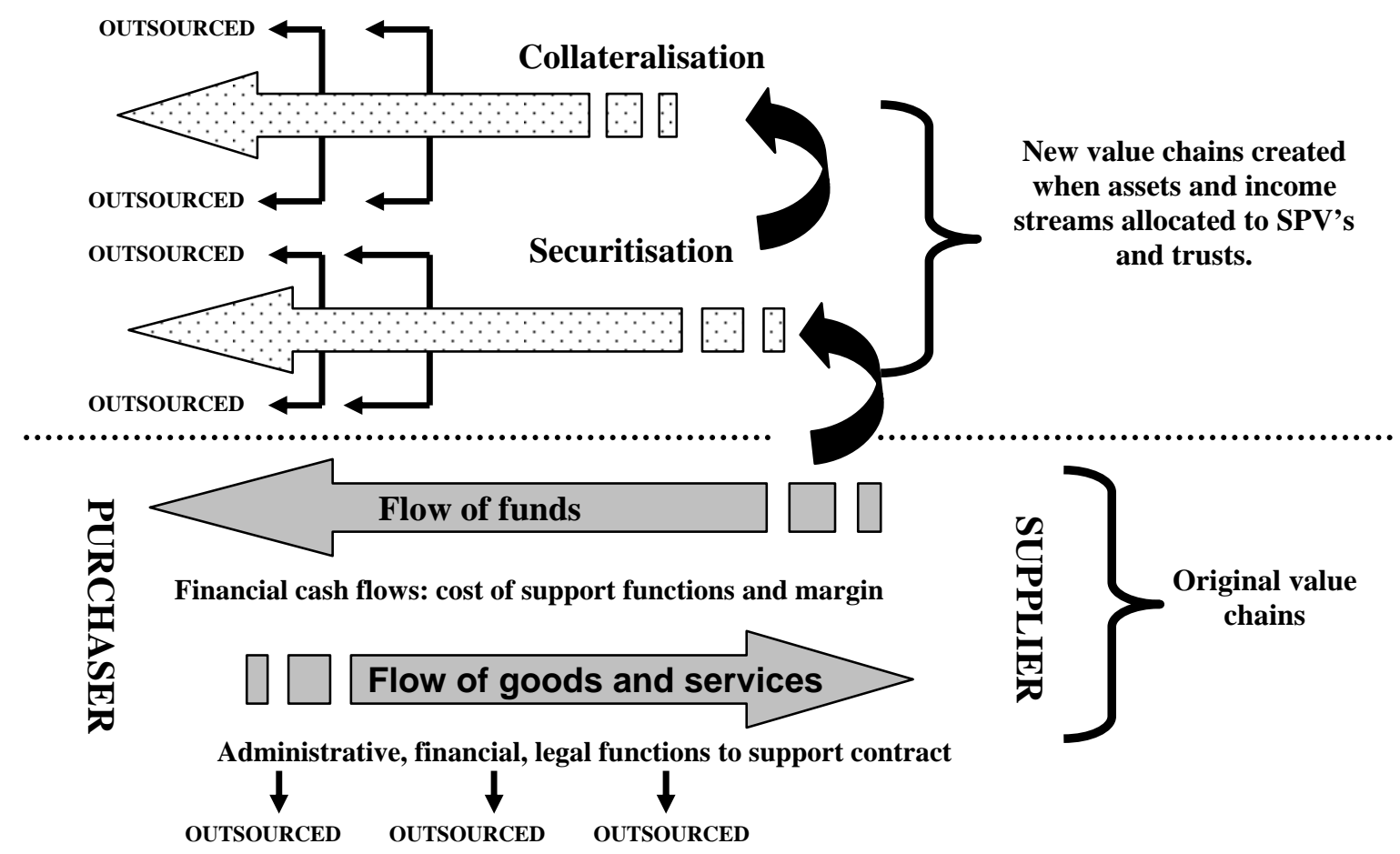

Source: Heilpern, 2008

Securitized mortgages sold on into special purpose vehicles (SPV) or trusts further fragments the financial value chain and inflates intermediation. These additional intermediaries are value skimming and need to drive up volume because each individual transaction carries a slim margin out of which bonuses and commission fees are paid and financial surplus extracted. Fragmenting the value chain increases the number of financial intermediation nodes but this has implications for inter-bank risk management because product risk becomes less visible and liquidity spread increasingly thin across an expanded value chain.

In the UK Northern Rock quite legitimately bundled up and then sold to a special trust some of its mortgages to raise additional funds upon which it could scale up its business. A special trust Granite, i.e. a Special Purpose Vehicle (SPV), acquired these mortgages, raising cash from issuing fixed interest bonds to pension funds and other investors within a complex 
pyramid of transactions. Northern Rock's income from household mortgage repayments transferred on to Granite, to service the interest paid to bond investors and other financial instruments issued.

Depending on the so-called risk appetite of bond-investors, banks can "dice and slice" securitized assets into differentiated credit rating risk classes. The theory behind this is the principle of risk diversification, through blending high-risk sub-prime loans with lower risk mortgage debt. The purpose of dicing and slicing banks asset backed securities is to diversify the risk to banks and bond investors through this blending. The primary objective here is to modify the credit rating of the securitized product not underlying capital market liquidity. Where risk management played out at the expense of liquidity.

However, although the initial motivation is to reduce risk and cost of capital the structuring of these transactions is located in a complex financial web where the visibility of payment information and risk assessment is less clear

The complexity of these financial products and payments structure(s) conceals risk and reduces liquidity across the value chain. In circumstances where household mortgage default rates increase securitized products that have blended varying types of credit risk in a complex transactions network become "contaminated". Contamination spreads across the banking sector, the wholesale markets, the retail markets, insurance companies, the asset management industry, and into the household. The situation further deteriorates when holders of securities have trouble finding other investors to buy these as the secondary mortgage market runs short of liquidity. Those holding these asset backed securities, and who took out financing to do so, may have margin calls that force them to trade, at a discount, what are illiquid underlying investments. Liquidity is further restricted because financially distressed banks will hold on to cash as an insurance against further charge off's of irrecoverable loans (net of recoveries).

Following SFAS 157 "Fair value measurements" and more specifically SFAS 144 “Accounting by Creditors for Impairment of a Loan” and SFAS 133 “Accounting for Derivative Instruments and Hedging Activities” charge off's of irrecoverable loans and discounted asset backed securities should be made with reference to the loans carrying value and "estimated fair value" of collateral securing the loan. Banks holding balances of securitized assets are required to re-value these assets to reflect their current market value in a distressed market. Holding losses charged off against net income have the potential to 
significantly reduce reported earnings per share, destabilise market valuation(s) and undermine capital adequacy ratios as shareholder equity held in the balance sheet is written down.

\section{Drivers of the US credit crunch}

Basu (1993) argues that banking business model is fragile because the credit standard (in a liberal and competitive market) does not protect banks loan portfolio from risk of default.

'in the non-uniform competitive conditions under which the financial sector operates, it is not always possible in all circumstances for bankers or lenders to introduce a uniform credit standard in order to protect their entire loan capital portfolio.' (Basu, 2003: 242)

A credit standard is required, according to Basu, to ensure that banks are able to recoup funds from 'the sale of collateral' if borrowers default. In turn, this may act to put a brake on the "contagion" effect where is the possibility of a run on highly exposed banks. A "credit standard” might help to limit financial damage to the banking sector. However, the argument developed in this next section is that fair value reporting and modest increases in mortgage default rates can undermine the financial stability of banks. Spaventa observes that mark-to market accounting “inflates banks profits and the returns of the asset management industry, to the advantage of share prices and managers remuneration” (Spaventa 2008: 5).

In the recent credit crunch accounting adjustments around fair value feed into a loss-making spiral where the mismatch between off-balance sheet maturity structures combines with valuation difficulties raising concern over counterparty risks and run-offs. Fair value accounting amplifies financial fluctuation(s) and restructuring response (s) over and above traditional historical cost accounting. The reason for this behaviour is that mark-to-market accounting induces endogenous volatility into market transactions and thus reported profitability (Platin et al 2008, Bernard et al 1995) where the "fair value" portrays a situation remote from long-term fundamentals and contributes to illiquidity through its effects on banks balance sheets (Spaventa, 2008 ) 
Fair value accounting has implications for governance and management of the economy especially in the banking sector where asset valuations and provisions for loan losses are booked at market value. Fair value adjustments are volatile and can quickly undermine net income, market valuation and the equity cushion in bank balance sheets. A relatively small increase in household mortgage default rates has seriously weakened banking operating financials and their balance sheet structure Table 4 reveals the value of residential mortgages charged off against net income and the balance sheet in the US banking and thrift sector. Residential estate loans charged-off are loans (adjusted for recoveries) that have been removed off the books and charged against loss reserves. At the start of the 1990's 0.21 per cent of residential loans were charged-off and after falling off the proportion of loans charged-off at the end of the decade and during a recession was still 0.17\%. During 2007, the charge-off rate increased and by Q4 2008 had reached 1.58\%. Estimates suggest the chargeoff rate could reach 2\% by end Q1 2009 (see fig.2) as market conditions continue to deteriorate and interest rates for adjustable rate mortgages (ARM's) increase putting more households into financial difficulty

Table 4: Estimate of US residential mortgages charged off against banking net income

\begin{tabular}{|c|c|c|c|c|}
\hline & $\begin{array}{l}\text { Residential } \\
\text { estate loans } \\
\text { charged off } \\
\end{array}$ & $\begin{array}{c}\text { Delinquency rate } \\
\text { on real estate } \\
\text { loans } \\
\end{array}$ & $\begin{array}{c}\text { US Household } \\
\text { Outstanding } \\
\text { Mortgages } \\
\end{array}$ & $\begin{array}{c}\text { Estimate of charged } \\
\text { off loans }\end{array}$ \\
\hline & $\%$ & $\%$ & $\$$ bill & $\$$ bill \\
\hline 1991 & 0.21 & 7.4 & 2,790 & 6 \\
\hline 1995 & 0.13 & 3.09 & 3,461 & 4 \\
\hline 2000 & 0.13 & 1.84 & 5,129 & 7 \\
\hline 2005 & 0.08 & 1.34 & 9,379 & 8 \\
\hline 2006 & 0.08 & 1.36 & 10,452 & 8 \\
\hline 2007 Q1 & 0.14 & 1.77 & 10,652 & 16 \\
\hline 2007 Q2 & 0.19 & 2.02 & 10,862 & 21 \\
\hline 2007 Q3 & 0.28 & 2.39 & 11,016 & 29 \\
\hline 2007 Q4 & 0.45 & 2.88 & 11,158 & 50 \\
\hline 2008 Q1 & 0.82 & 3.52 & 11,226 & 95 \\
\hline 2008 Q2 & 1.13 & 4.33 & 11,300 & 132 \\
\hline 2008Q3 & 1.45 & 5.00 & 11,000 & 163 \\
\hline 2008 Q4 & 1.58 & 6.29 & 10,092 & 175 \\
\hline
\end{tabular}

http://www.federalreserve.gov/releases/chargeoff/

Notes: Charge-offs are the value of loans and leases removed from the books and charged against loss reserves. Charge-off rates are annualized, net of recoveries. 2008Q3 (estimated).

Delinquent loans and leases are those past due thirty days or more and still accruing interest as well as those in nonaccrual status. Data for residential estate loans charged off and delinquent is for the first quarter of each year 
Adding together real estate, commercial real estate and household credit card loans charged off total charge offs increase from \$175bn to \$330bn and equivalent to 28 percent of US banking sector equity. While the value of loans charged off and loans delinquent (past 30 days due) would be equivalent to writing off all the equity employed in US banks as at the end of the year 2008 ( $\$ 12$ trillion)

Figure 2:

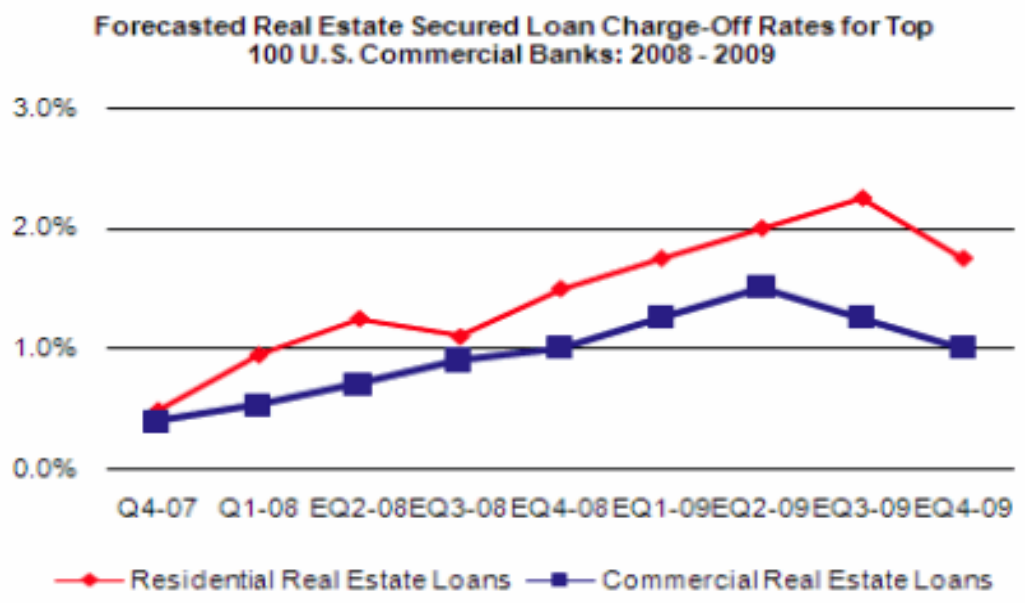

http://www.researchrecap.com/index.php/2008/08/22/charge-off-rate-for-us-banks-to-peak-in-mid-2009/

Although the charge off rate is small in percentage terms a one-percentage point increases translates into a significant charge off against banking net income. We estimate that actual charge-off's against US banking sector net income will have increased from approximately \$16 billion as at the first quarter 2007 to roughly \$200 billion by the first quarter 2009 .

Table 5: FDIC member loan net charge-off's by type

\begin{tabular}{|l|r|r|r|r|r|r|}
\hline Year end & $\begin{array}{r}\text { Dec-08 } \\
\text { \$ bill }\end{array}$ & $\begin{array}{c}\text { Jun-08 } \\
\text { \$ bill }\end{array}$ & $\begin{array}{c}\text { Jun-07 } \\
\text { \$ bill }\end{array}$ & $\begin{array}{c}\text { Jun-06 } \\
\text { \$ bill }\end{array}$ & $\begin{array}{c}\text { Jun-05 } \\
\text { \$ bill }\end{array}$ & $\begin{array}{c}\text { Jun-04 } \\
\text { \$ bill }\end{array}$ \\
\hline Net charge off's & 87.9 & 46.0 & 17.1 & 11.5 & 13.9 & 16.6 \\
Real estate loans & 38.5 & 22.5 & 2.9 & 1.1 & 1 & 1.2 \\
Credit cards & 19.5 & 10.3 & 7.4 & 6.1 & 8.4 & 8.9 \\
Commercial and Industry & 13.2 & 5.7 & 2.5 & 1.4 & 1.4 & 2.8 \\
Other & 16.3 & 7.5 & 4.3 & 2.9 & 3.1 & 3.7 \\
\hline
\end{tabular}

http://www.fdic.gov/index.html 
The US Federal Deposit Insurance Corporation (FDIC) insures checkable deposits for member banks and saving/thrift institutions and publishes information on loan charge off's (after recoveries) which are split into varying categories including: real estate loans, commercial and industrial loans and credit cards. In table 5 we summarise the position on net charge offs, from the FDIC, for the period year ending June 2004 to year ending December 2008 (see table 5).

Between June 2007 and December 2008 there is a substantial jump in the value of aggregate residential estate loan charge offs against FDIC member banks and savings institutions net income. Two-thirds of the increase in charge offs during this period resulted from the increase in irrecoverable real estate loans. Out of the total increase of $\$ 60 \mathrm{bn}$ sixty percent of this was due to real estate loans and the remainder $\$ 9$ billion the increase in credit cards and commercial and industry loans and other loans losses.

Table 6: FDIC member annual financials 2007 - 2008

\begin{tabular}{|l|c|c||}
\hline Income data mill \$ & 2008 & 2007 \\
\hline Net interest income & 357.7 & 352.7 \\
Provision for loan and lease losses & $\mathbf{- 1 7 4 . 3}$ & $\mathbf{- 6 9 . 1}$ \\
\hline Total non-interest income & 207.6 & 233.0 \\
\hline \hline Total non-interest expense & 358.7 & 367.0 \\
Securities Gains (losses) & -14.9 & -1.4 \\
Income taxes & -6.7 & -46.4 \\
Extraordinary gains & 5.3 & -1.7 \\
\hline Net Income & $\mathbf{1 6 . 0}$ & $\mathbf{9 9 . 9}$ \\
\hline Cash Dividends & 50.9 & 110.3 \\
Retained Income & -34.9 & -10.3 \\
Return on Assets \% & $\mathbf{0 . 1 2}$ & $\mathbf{0 . 8 1}$ \\
Return on Equity \% & $\mathbf{1 . 2 4}$ & $\mathbf{7 . 7 5}$ \\
\hline
\end{tabular}

Source: http://www2.fdic.gov/qbp/2008dec/qbp.pdf

Note: Return on assets and equity are annualised for the year ended June 2008 and June 2007

Figures in columns will not add up as key financial data has been taken from the financial statement.

The increase in residential loan charge offs has significantly undermined reported net income of FDIC members as they make increased provision for loan losses.

Net income for all of 2008 was $\$ 16.1$ billion, a decline of $\$ 83.9$ billion (83.9 percent) from the $\$ 100$ billion the industry earned in 2007 . This is the lowest annual earnings total since 1990 , when the industry earned $\$ 11.3$ billion. 
In 2008 FDIC members charged \$174 billion against profit compared to \$69 billion in 2007 reducing net income from $\$ 100$ billion to $\$ 16$ billion a drop of 84 percent. Chart 5 reveals the net income reported by a sample US banks with $\$ 10$ trillion of assets under management. In Q1 2007, this group of banks reported a positive net income of \$30bn and in Q3 2008 a net loss of £40bn driven by asset write down and goodwill impairments. For the same period, the market value of this group of banks fell from $\$ 1.3$ trillion to $£ 690$ bn a loss of $47 \%$.

Chart 5 Net income (losses) reported by US banks 2007 to 2008

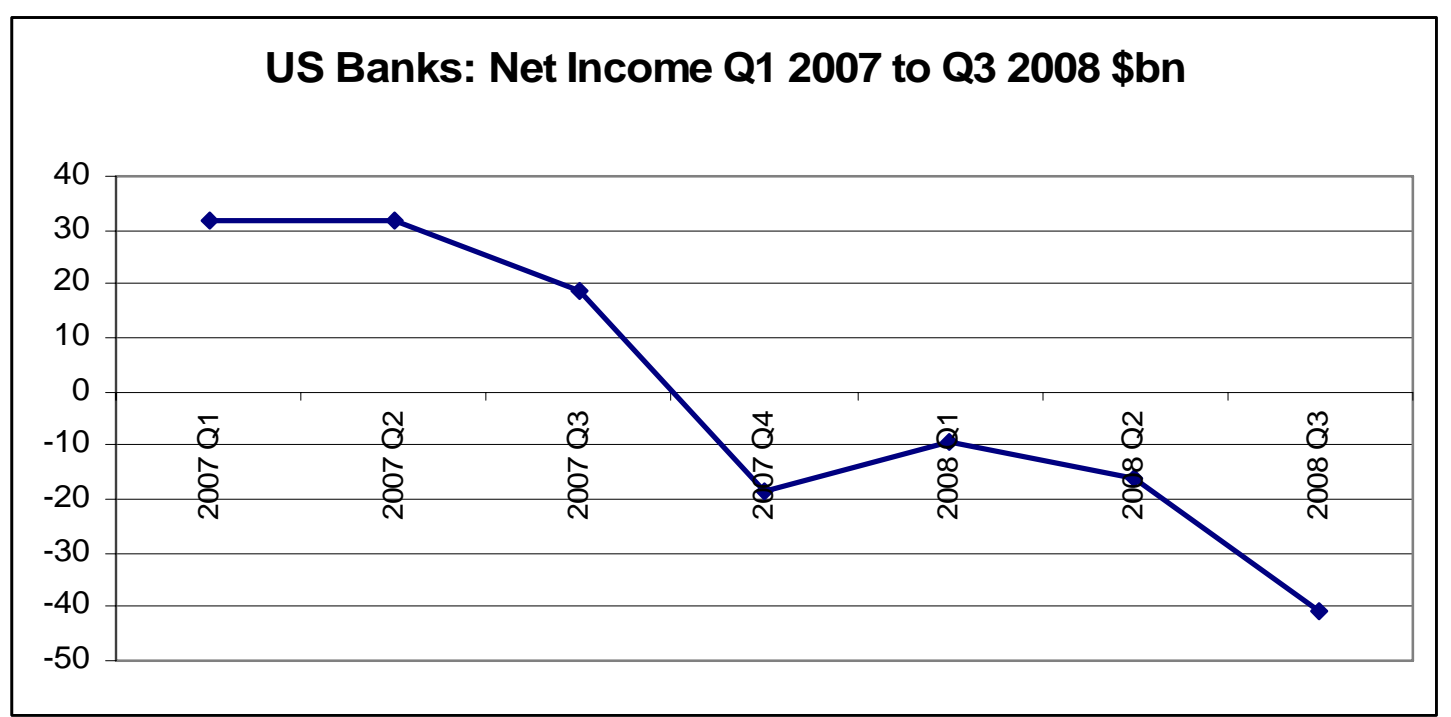

Source: Edgar dataset (http://www.sec.gov/edgar.shtml) 8K’s and company web pages.

Wachovia Corporation is the $4^{\text {th }}$ largest bank holding company in the US with balance sheet assets totalling £800bn but exposure to mortgage charge off’s and provisions for credit losses has undermined reported net income, market valuation and balance sheet equity. 
Table 7: Wachovia loans, credit losses and net income Q3 2007 to Q3 2008

\begin{tabular}{|l|c|c|c|c|c|}
\hline & $\begin{array}{c}\text { Loans } \\
\text { net } \\
\text { \$ bn }\end{array}$ & $\begin{array}{c}\text { Provision } \\
\text { for credit } \\
\text { losses } \\
\text { \$ bn }\end{array}$ & $\begin{array}{c}\text { Provisions } \\
\text { as of net } \\
\text { loans } \\
\%\end{array}$ & $\begin{array}{c}\text { US } \\
\text { average } \\
\%\end{array}$ & $\begin{array}{c}\text { Net income } \\
\text { before goodwill } \\
\text { impairment } \\
\$ \text { bn }\end{array}$ \\
\hline 2007 Q3 & 449.2 & 0.4 & 0.09 & 0.23 & 2.6 \\
2007 Q4 & 461.9 & 1.5 & 0.32 & 0.42 & 0.1 \\
2008 Q1 & 480.4 & 2.8 & 0.58 & 0.69 & -0.7 \\
2008 Q2 & 488.2 & 5.7 & 1.17 & 1.01 & -4.8 \\
2008 Q3 & 482.3 & 6.6 & 1.37 & 1.5 & -7.6 \\
\hline
\end{tabular}

Source: Edgar dataset, SEC Washington, 8K's and company website

http://www.wachovia.com/inside/page/0,133_205_300,00.html

For the period, Q3 2007 to Q3 2008, Wachovia reported increased provisions for credit loss rising from $0.09 \%$ to $1.37 \%$ of total loans and roughly in line with US banking sector averages. Although this is a small percentage of loans under management (1.37\% of \$482bn) this translates into a \$6.6bn provision which is large when net revenues were just \$6bn in Q3 2008. Overall, this forced Wachovia into a net loss of \$7.6 bn in Q3 2008 after covering all non-interest expenses.

Significantly, a large proportion of actual and anticipated credit losses originated out of the Golden West Financial Corporation of Oakland, California which had been acquired by Wachovia for \$25.5bn in 2006. Specifically Golden West specialized in "Pick a Payment" loans accounting for $\$ 119 \mathrm{bn}$ out of $\$ 482 \mathrm{bn}$ of mortgages issued on Wachovia’s balance sheet as at September 2008. "Pick a Payment" loans allowed the borrower to choose from four payment options: a minimum payment, interest only, a fully amortising 15-year payment and a fully amortising 30-year payment term. Of those taking out "Pick a Payment” loans 85\% had applied using the “Quick Qualifier” programme where "As a result, loans in the 'Quick Qualifier’ programme may have varying levels of income and asset verification” (Wachovia 10Q, Oct 2008).

"Substantially all of the Golden West mortgage portfolio has consisted of a product, referred to as “option ARMs” or adjustable rate mortgages with monthly payment options. The credit 
quality of this portfolio has deteriorated significantly in the current mortgage crisis” (Well Fargo S-4: 37)

http://www.wachovia.com/file/Wells_Fargo-Wachovia_S-4(Filed).pdf

At the end of September 2008 two-thirds of Wachovia's “Pick a Payment” loans were in the form of the 'minimum monthly payment' and so those taking out these loans were building up 'negative amortisation' because the total amount owing increased as the outstanding loan included the unpaid interest on top of the original loan. Deferred interest on these loans amounted to \$4.1bn as at the end of Q3 2008. During the period, Q3 2007 to Q3 2008, Wachovia increased provisions for credit losses from its "Pick a Payment" asset class. In a recent presentation (September 2008), Wachovia managers revealed that out of the \$119bn of outstanding pick a payment mortgages they expected that a further $\$ 23 \mathrm{bn}$ or $22 \%$ of this class of mortgages would need to be charged off against income. http://www.wachovia.com/file/WB3Q08_Presentation.pdf

Wachovia's problems were concentrated in a mortgage asset class underwritten by thin documentation on the lenders finances and offered two thirds of these borrowers a minimum payment "credit card" style mortgage repayment plan. On the downside, this class of mortgages resulted in a substantial write down in Wachovia's net income and reported net income per share.

Table 8: Wachovia market value Q3 2007 to Q3 2008 (\$bn)

\begin{tabular}{|l|c|c|}
\hline & Market value \$ bn & Index \\
\hline 2007 Q3 & 95.3 & 100.0 \\
2007 Q4 & 75.3 & 79.0 \\
2008 Q1 & 53.8 & 56.4 \\
2008 Q2 & 33.5 & 35.2 \\
2008 Q3 & 14.1 & 14.7 \\
\hline
\end{tabular}

Source: http://www.wachovia.com/inside/page/0,133_205_300,00.html

As net earnings per share (EPS) collapsed this also triggered a reduction in the price of Wachovia's share price and aggregate market value which dropped from \$95bn to \$14bn (a loss of 85\%) for the five quarters ended Q3 2008. This drop in market value triggered by the deteriorating performance of Golden West then forced a goodwill write down of \$18.8bn. 
Goodwill impairment testing

- $\quad$ As of September 30, 2008, resulted in $\$ 18.8$ billion pre-tax impairment

- $\quad \$ 18.7$ billion after-tax as only a small percentage of goodwill is tax deductible

Drivers of impairment was declining market valuation and terms of the merger with

Wells Fargo

http://www.wachovia.com/file/WB3Q08_Presentation.pdf

Goodwill impairments totalling \$24.9bn accelerate the deterioration in Wachovia’s operating financials. Shareholder equity already thinned down by a programme of $\$ 20.5 \mathrm{bn}$ of share buy-backs (1990 to 2007) further eroded by the goodwill impairment charge lodged in the accounts in Q3 2008

Table 9: Wachovia net loss after goodwill impairment

\begin{tabular}{|c|c|c|c|c|c|}
\hline & $\begin{array}{c}\text { Income } \\
\text { \$bn }\end{array}$ & $\begin{array}{c}\text { Net income pre } \\
\text { goodwill impairment } \\
\text { \$bn }\end{array}$ & $\begin{array}{c}\text { Goodwill } \\
\text { impairment } \\
\text { \$bn }\end{array}$ & $\begin{array}{c}\text { Net income/ } \\
\text { loss } \\
\text { \$bn }\end{array}$ & $\begin{array}{c}\text { Total } \\
\text { Equity } \\
\text { \$bn }\end{array}$ \\
\hline 2007 Q3 & 7.5 & 2.6 & & 2.6 & 70.1 \\
2007 Q4 & 7.4 & 0.1 & & 0.1 & 76.9 \\
2008 Q1 & 7.6 & -0.7 & & -0.7 & 78.0 \\
2008 Q2 & 7.5 & -4.8 & 6.1 & -10.8 & 75.1 \\
2008 Q3 & 5.8 & -7.6 & 18.8 & -26.4 & 50.0 \\
\hline
\end{tabular}

Source: http://www.wachovia.com/inside/page/0,133_205_300,00.html

At the end of the period covered in table 9 the collapse of Wachovia's financials and reduction of market value coincided with disclosures by the banks management revealing that liquidity was strained and the bank had limited unencumbered assets upon which it could raise further capital. Without a rescue deal, it would go into liquidation and holders of common stock "would likely receive no material value”.

At the start of October 2008 Wells Fargo agreed to purchase Wachovia after hasty negotiations. Perella Weinberg provided opinions on the deal to Wachovia stockholders disclosed in the S-4 documentation provided on the merger to shareholders.

“diligence of Wells Fargo was limited to publicly available information, including publicly available estimates of certain research analysts covering Wells Fargo, and did 
not include discussions with management or representatives of Wells Fargo or other diligence that it would customarily conduct in connection with preparing a fairness opinion” (S4:55)

Moreover, in the rush Perella Weinberg sought advice and reassurance as to the quality of Well Fargo’s balance sheet from Wachovia management.

"Perella Weinberg is not an expert in the valuation of loan or mortgage portfolios or securities relating to loan or mortgage portfolios, or allowances for losses with respect thereto, and accordingly, did not evaluate the same with respect to Wachovia or Wells Fargo, and assumed, with the consent of Wachovia's board of directors, that Wells Fargo’s allowances for such losses were adequate to cover all such losses” (S4:55).

\section{(http://www.wachovia.com/file/Wells_Fargo-Wachovia_S-4(Filed).pdf)}

Wells Fargo S-4 documentation on the merger between the two companies reveals the cost of acquiring Wachovia to be $\$ 24.5 \mathrm{bn}$, that is, the cost of acquiring the market value of outstanding share capital and preferred stock. The fair value of Wachovia's assets assessed at just $\$ 10 \mathrm{bn}$. The book value of equity ( $\$ 50 \mathrm{bn}$ ) now reduced by a further $\$ 40 \mathrm{bn}$ in respect of anticipated future charge offs of non-performing loans.

Table 10 Extract from Wells Fargo S-4 purchase cost of Wachovia \$bn.

\begin{tabular}{|l|c|}
\hline & As at Sept 30th 2008 \\
\hline Purchase price of shares & 14.7 \\
\hline Preferred stock acquired & 9.8 \\
\hline Purchase consideration & 24.5 \\
\hline Of which : Goodwill & $(14.5)$ \\
\hline Fair value of assets & 10 \\
\hline
\end{tabular}

http://www.wachovia.com/file/Wells_Fargo-Wachovia_S-4(Filed).pdf

Note: Wachovia equity value as at Sept $30^{\text {th }} 2008$ was $\$ 50$ bn and expected future loan losses \$40bn 
In the nine months to Sept 2008 Wells Fargo had made allowances for loan losses equivalent to $1.9 \%$ of loans (\$422bn) compared to Wachovia’s 3.2\% (on $\$ 482 \mathrm{bn}$ ). The balance sheet position of Wells Fargo may be somewhat more secure but volatility of capital conditions makes it less than certain that the amalgamation of these two banks will establish a bigger and more robust business.

In the US, banking sector the net income margin(s) on assets employed is very slim averaging just $1 \%$ in 2007. A small increase in the number of households defaulting on their mortgages quickly translates into a large loss of earnings and increased market value at risk. Mark to market accounting (Andersson et al 2008) further amplifies financial adjustments, for example, triggering goodwill impairment(s) charged-off against net income and shareholder equity. Shareholder equity averaged just $8-10 \%$ of total banking sector assets in the US banking sector in 2007 after share buy-backs for treasury stock and executive bonus schemes had depleted this safety cushion in the balance sheet.

\section{$\underline{\text { Discussion and conclusions }}$}

The drivers of the current crisis in US banking sector have their origin in the relaxation of regulatory conditions that decoupled the increase in stock of mortgages outstanding from bank deposits and GDP growth. The sheer scale of real estate mortgage debt outstanding, range of financial products available fuelled by incentives to drive up sales, margins and value skim increased the probability of higher default rates in a downturn. The technical arguments for mortgage securitization have centred on the advantages to banks focussing on the management of balance sheet risk, risk diversification and extending funds for lending beyond the limits set by deposit taking.

It is clear that existing credit risk models were not seriously anticipating the possibility that household default rates would increase because the behaviour and lending practises of US banks inflated risk exposure. The development of "ALT A" and "Pick a Payment” mortgages coupled with thin documentation and assessment of household assets and quality of earnings established the precondition that default rates would increase when market conditions changed. The underlying risk attached to these loans concealed during a period when house 
prices were inflating, loan to asset values falling, and equity release mortgages on the increase. When economic conditions deteriorated household credit risk and sub-prime mortgage default rates came to the surface.

Relative to the total value of US mortgages outstanding charge offs and default rates are low in percentage terms. However, small adverse movements do matter because the scale of mortgages outstanding, by value, is significant and banks operate with fragile financial operating ratios and a thin margin of safety. The Federal Deposit Insurance Corporation (FDIC) reports that the during the period 2002 to 2007 the average US bank reported net income to total assets of $1.23 \%$. This means that if mortgage default rates do go above $1 \%$ of asset value this would force most banks into losses. Net earnings of FDIC reporting banks have collapsed as the level of charge offs exceeded 1\% of mortgage assets in Q2 and Q3 2008. As earnings per share collapsed this, in turn, impacts negatively on the market value of US banks and forces banks like Wachovia into defensive restructuring and charges for goodwill impairment.

Goodwill impairment is often a significant "lumpy" charge against net income. Goodwill held on US bank balance sheets was equivalent to 5 years worth of net income and $45 \%$ of shareholder equity as at the end of the financial year 2007. Credit losses and goodwill impairment(s) could reduce shareholder equity to the point where many banks are no longer a "going concern". FDIC financial datasets on insured commercial banks reveal the cushion of shareholder equity to be just $10 \%$ of total assets employed.

A number of drivers have contributed to the growth in household mortgages outstanding in the US. It was inevitable that as economic conditions deteriorated US households, aggravated by the lending practises of US banks, would default on loans. It is also clear that the financial architecture structuring the foundations of the US banking sector business model cannot sensibly resist the negative financial momentum arising from charge offs and goodwill impairment because the net income and equity to asset coverage ratios are thin and fragile.

Accounting regulation(s) are 'socially constructed' often reflecting the variable claims of different stakeholders the dominance of which changes over time. In recent years the US Finance Accounting Standards Board (FASB) has been concerned to reflect the interest of shareholder-investors in accounting standards with the result that the US banking and non- 
financial corporate sector has been required to mark to market. Mark to market accounting reflects the market value of corporate-capital market transactions in the balance sheet on behalf of shareholders. In a world where capital markets are inflating holdings gains can be extracted from assets held on balance sheet and recycled into income and back into wealth accumulation. However, we also know that, if the future is like the past, product and capital markets will not continue to grow all of the time. There are thus profound consequences for economic stability, financial risk assessment and asset valuation when the gains and losses from wealth accumulation are blended into current income statements when markets do turn down. The US Government has recently poured another \$20bn into Bank of America and Citigroup and AIG reported net losses of $£ 128 \mathrm{bn}$ as at the end of the financial year 2008. In the UK Royal Bank of Scotland and Lloyds banking group reported a net loss of \$70bn and billions employed to soak up toxic irrecoverable loans. It is now time to re-think the way in which we regulate the banking sector. The agenda for change should focus on limiting the risk to society that arises from an incentive driven wealth accumulating credit based system that is underwritten by a non viable banking business model. We could usefully start by removing incentives and the technical ability to inflate balance sheet assets ahead of GDP, net income and balance sheet shareholder funds. 
References

Altunbas, Y.,Gambacorta, L. and Marqués, D. (2007) Securitisation and the bank lending channel, European Central Bank, Working Paper 838.

http://www.ecb.int/pub/pdf/scpwps/ecbwp838.pdf

Andersson,T., Haslam, C., Lee, E., and Tsitsianis,N. (2008) Financialization directing strategy. Accounting Forum (forthcoming)

doi:10.1016/j.accfor.2008.08.001

Basu, S. (2003) Why do banks fail? International Review of Applied Economics. 17(3):231248

Bernard,V.L., Merton, R.C., and Krishna, G.P (1995) Mark-to-Market Accounting for Banks and Thrifts: Lessons from the Danish Experience. Journal of Accounting Research. 33(1): 132.

Darrell Duffe, Innovation in Credit Risk Transfer: Implications for Financial Stability.

Stanford University, 2007.

http://www.moodyskmv.com/conf08/papers/inno_cred_risk_xfer.pdf

Deeg, R. and O'Sullivan, M. 2006. The Financialization of Europe: The Evolution of Finance Capital in Britain, France, Germany, and Italy. American Political Science Association, Marriott, Loews Philadelphia, and the Pennsylvania Convention Center, Philadelphia, PA.

Financial Accounting Standards Board (FASB, 2001) SFAS 157

http://www.fasb.org/st/summary/stsum157.shtml

Financial Accounting Standards Board (FASB, 2001) SFAS 144

http://www.fasb.org/st/summary/stsum144.shtml

Financial Accounting Standards Board (FASB, 1998) SFAS 133

http://www.fasb.org/st/summary/stsum133.shtml

Federal Bureau Reserve (2007), The 2006 HMDA data. Federal Reserve Bulletin, 93:A73A109.

http://www.federalreserve.gov/pubs/bulletin/2007/pdf/hmda06draft.pdf

Fligstein, N. 2004. The end of (shareholder value) ideology? Institute for Research on Labor and Employment Working Paper Series Paper iirwps-116-05.

Foster, J.B.2007. The Financialization of Capitalism, Monthly Review. 58:11

http://www.monthlyreview.org/0407jbf.htm

Frankel,A. 2006. Prime or not so prime? An exploration of US housing finance in the new century. BIS Quarterly Review 67-78.

http://www.bis.org/publ/qtrpdf/r_qt0603f.pdf 
Froud, J., Johal, S., Leaver, A. and Williams, K. 2006. Financialization and Straetgy: Narrative and Number's. Routledge, Taylor and Francis, London

Geradi,K., Rosen, H.S., and Willen, P. 2006. Do Households Benefit from Financial Deregulation and Innovation? The Case of the Mortgage Market. Discussion Paper 06-6. Federal Reserve Bank of Boston. http://emp.hudson.org/files/publications/Gerardi_Rosen_Willen_9-2006.pdf

Greenspan, A. 2005. Current account. Remarks by Alan Greenspan at Advancing Enterprise Conference, London, England February 4, http://www.federalreserve.gov/boarddocs/speeches/2005/20050204/default.htm

Heilpern, E. 2008. The impact of disintermediation, outsourcing, and institutional risk, on today's global banking value chain; University of Hertfordshire, Hatfield http://rvametrics.com/publishedreports/

Jacobides, M.G 2003. How do markets emerge: Organizational unbundling and vertical disintegration in mortgage banking? Centre for the Networked Economy London Business School, Working Paper

Keys, B. J., Mukherjee,T., Seru A, and Vig,V. 2008. Did Securitization Lead to Lax Screening? Evidence from Subprime Loans.

http://www.moodyskmv.com/conf08/papers/secur_lax_screening.pdf

Krinsman A, N. 2007. Subprime Mortgage Meltdown; How did it Happen and How will it End? The Journal of Structured Finance, Vol XIII, (2)

Krippner, G. R. 2005. The Financialization of the American Economy. Socio-Economic Review 3: 173-208.

Martin, R. 2002. Financialization of Daily Life. Temple University Press: Philadelphia. 20.

Mason, D.L.2004. From Buildings and Loans to Bail-Outs: A History of the American Savings and Loan Industry, 1831-1995. New York: Cambridge University Press.

McCarthy, J and Peach, R, W. 2005 Are Home Prices the Next Bubble?. Federal Reserve Bank of New York Policy Review

Petersen, M. A and Rajan, R.G. 2002. Does Distrurbance Still Matter? The Information Revolution in Small Business Lending. Journal of Finance 57 (6): 2533-2570.

Platin,G., Sapra, H., and Shin H.S. 2008. Marking-to-Market: Panacea or Pandora's Box. Journal of Accounting Research, 46 (2): 435-460.

http://faculty.chicagogsb.edu/finance/papers/mtm.pdf

Rossman, P and Greenfield, G. 2006. Financialization: New routes to profit, new challenges for trade unions. Labour Education, ILO Bureau for Workers' Activities: 142. 
Shiller, R. J. (2006a). Asset Prices, Monetary Policy, and Bank Regulation.

http://www-tc.pbs.org/nbr/site/images/shillerbankStructureChicagoFed03.pdf

Schiller, R.J (2006b). Long-Term Perspectives on the Current Boom in Home Prices.

Economists'Voice, 3, (4:4)

http://www.bepress.com/ev/vol3/iss4/art4

Schnure, C. 2005. Boom-Bust Cycles in Housing: The Changing Role of Financial Structure. IMF Working Paper (WP/05/200)

http://www.imf.org/external/pubs/ft/wp/2005/wp05200.pdf

Spaventa,L. 2008. Avoiding Disorderly Deleveraging. CEPR Policy Insight, no 22 (May 2008), Centre for Economic Policy Research. www.cepr.org http://www.cepr.org/pubs/PolicyInsights/PolicyInsight22.pdf

Standard and Poor's -Case Shiller Index House Price Values http://www2.standardandpoors.com/portal/site/sp/en/us/page.topic/indices_csmahp/0,0,0,0,0, $\underline{0,0,0,0,1,1,0,0,0,0,0 . h \mathrm{hml}}$

Stockhammer, E. 2004. Financialization and the slowdown of accumulation, Cambridge Journal of Economics, 28: 719-741. 